\title{
An assessment of the Problems faced by Karachi and Pakistan due to the rapid population growth of the city
}

\author{
Moiz Khan* \\ Hina Khan**
}

\begin{abstract}
Karachi is one of the fastest growing city in the world. Since the independence of Pakistan, Karachi has emerged as a mega polis catering to the largest population in all across the country. Karachi has earned the reputation of melting pot of all ethnic shades of Pakistan. The city also serves as the financial capital of Pakistan. All banks, financial institutions, national and international organizations have their headquarters in Karachi. It also has the highest literacy rate in Pakistan. However all this was not achieved without a cost. Due to its development more and more people from all across Pakistan still want to make Karachi their destination for fulfilment of their dreams. This constant migration into the city has made it the most unmanageable city of Pakistan too. The authorities fail to provide services to its citizens on the pretext of lack of funding and incapacity. This study focuses on the issues faced by Karachi and indirectly by Pakistan due to the ever increasing size and population of the city. The study also highlights the reasons for the various problems of the city and the impediments towards addressing them.
\end{abstract}

Keywords: Karachi, Pakistan, population, economy, migration and planning.

*Assistant Professor, Department of General History, University of Karachi

**Assistant Professor, Department of General History, University of Karachi 


\section{Introduction and the estimate of the issues: Karachi: The largest metropolitan of Pakistan}

Karachi is the largest city of Pakistan (in terms of area and population) today. According to 1998 census report the population of Karachi was "9856318 persons" 1 The population of Karachi according to recent official records is 12 million people, however, the unofficial estimates and other circumstantial evidences approximately estimates twenty million at present.

Top ten cities of the world in terms of population:

\begin{tabular}{|l|l|l|l|}
\hline S.no. & City & Country & Population \\
\hline 1 & Tokyo & Japan & $37,126,000$ \\
\hline 2 & Jakarta & Indonesia & $26,063,000$ \\
\hline 3 & Seoul & South Korea & $22,547,000$ \\
\hline 4 & Delhi & India & $22,242,000$ \\
\hline 5 & Shanghai & China & $20,860,000$ \\
\hline 6 & Manila & Philippines & $20,767,000$ \\
\hline 7 & Karachi & Pakistan & $20,711,000$ \\
\hline 8 & New York & USA & $20,464,000$ \\
\hline 9 & Sao Paulo & Brazil & $20,186,000$ \\
\hline 10 & Mexico City & Mexico & $19,463,000$ \\
\hline
\end{tabular}

\section{Table $1.1^{2}$}

Since the turn of the twentieth century population shift from rural to urban areas is noticed globally. Cities of the developing world have gone through massive increase in population. According United Nations estimates this trend will continue and by 2025 five billion people $(61 \%$ of the total world population), will be living in cities $^{3}$.

However, the study of phenomenal increase in Karachi's population presents some unique reasons. In the case of Karachi reasons are in hybrid and convoluted among social, political, economic spheres.

\footnotetext{
http://www.census.gov.pk/SINDH/KARACHI.htm Accessed December 12, 2012

http://www.worldatlas.com/citypops.htm Accessed February 26, 2014

3 Eugene Linden, "The Exploding Cities of the Developing World," Foreign Affairs, Vol. 75, No. 1 (Jan. - Feb., 1996): 54, Accessed May 21, 2012, http://www.jstor.org /stable/20047467
} 


\section{Fastest growing city of Pakistan:}

Karachi is the fastest growing city in the World today. Karachi has grown from a population of mere $10000^{4}$ people to 16 million within 160 years. The average would be one million in a decade which is quite remarkable. In comparison to other mega cities of the world like New York, Mumbai, Tokyo, London, Delhi, Singapore, the history of Karachi as a city starts after the conquest of Sindh in 1843.

"Karachi is one of the fastest growing cities in Asia. Its population has almost doubled during the past 15 years. With a population estimated 9.5 million in 1995(which is an underestimate), the United Nations (1994) ranked Karachi as the $18^{\text {thlargest }}$ city of the world and projected population of 20.6 million by the year 2015, it will be ranked as the seventh largest city in the world. Thus, just in the next 20 years, Karachi's population is expected to exceed the populations of New York, Mexico City, Los Angeles, Beijing, Calcutta, Seoul, Buenos Aires, Osaka, Tianjin, Rio de Janeiro, and Delhi"5.

Population Growth in Karachi and Pakistan, 1901-2001

\begin{tabular}{|l|l|l|l|l|l|}
\hline \multicolumn{3}{|c|}{ Karachi } & \multicolumn{2}{c|}{ Pakistan } \\
\hline Years & $\begin{array}{l}\text { Population } \\
\text { (in 000) }\end{array}$ & $\begin{array}{l}\text { \%Increase } \\
\text { in 20 } \\
\text { years }\end{array}$ & $\begin{array}{l}\text { \% Annual } \\
\text { Growth } \\
\text { Rate }\end{array}$ & $\begin{array}{l}\text { \% } \\
\text { Increase } \\
\text { in 20 } \\
\text { years }\end{array}$ & $\begin{array}{l}\text { \%nnual } \\
\text { Anowth } \\
\text { Rate }\end{array}$ \\
\hline 1901 & 117 & -- & -- & -- & -- \\
\hline 1921 & 217 & 85 & 3.1 & 27 & 1.3 \\
\hline 1941 & 387 & 75 & 3.0 & 34 & 1.5 \\
\hline 1961 & 1,917 & 400 & 8.4 & 52 & 2.1 \\
\hline 1981 & 5,208 & 175 & 4.5 & 96 & 2.6 \\
\hline 1995 & 9,909 & -- & 4.3 & -- & 2.6 \\
\hline 2001 & 12,406 & 138 & 4.0 & 88 & 2.3 \\
\hline 2015 & 20,600 & 108 & 3.2 & 63 & 2.1 \\
\hline
\end{tabular}

4 See, Richard F. Burton, Scinde or The Unhappy Valley Vol. 1 (London: Richard Bentley, 1851)

5 Mehtab S. Karim, "Changing Demographic, Social and Economic Conditions in Karachi City, 1959-94: A Preliminary Analysis," The Pakistan Development Review, 34: 4 Part III (Winter 1995): 1094, Accessed December 24, 2011. http://www.pide.org.pk Lpdf/PDR/1995/Volume4/1093-1106.pdf. 


\section{Table $1.2^{6}$}

Interestingly the population growth rate of Karachi is increasing by leaps and bounds because of misdirected and exclusive development strategies of successive governments. The development in Pakistan has not taken shape as a result of proper planning and policy. Consecutive governments have failed to identify the development issues in Pakistan. Consequently the cities of Pakistan have become the victim of uneven development. Karachi, being the fastest growing industrial city, was the worst-hit city of Pakistan.

\section{Population of major cities of Pakistan}

\begin{tabular}{|l|l|l|c|l|l|}
\hline S.no & City & $\begin{array}{l}\mathbf{1 9 9 8} \\
\text { Census }\end{array}$ & $\begin{array}{l}\mathbf{1 9 8 1} \\
\text { Census }\end{array}$ & $\begin{array}{l}\text { CAGR } \\
\text { (\%) }\end{array}$ & $\mathbf{2 0 1 0}$ \\
\hline 1 & Karachi & $9,339,023$ & $5,208,132$ & 3.49 & $13,386,730$ \\
\hline 2 & Lahore & $5,143,495$ & $2,952,689$ & 3.32 & $7,214,954$ \\
\hline 3 & Faisalabad & $2,008,861$ & $1,104,209$ & 3.58 & $2,912,269$ \\
\hline 4 & Rawalpindi & $1,409,768$ & 794,834 & 3.43 & $2,013,876$ \\
\hline 5 & Multan & $1,197,384$ & 732,070 & 2.93 & $1,610,180$ \\
\hline 6 & Hyderabad & $1,166,894$ & 751,529 & 2.62 & $1,521,231$ \\
\hline 7 & Gujranwala & $1,132,509$ & 600,993 & 3.79 & $1,676,357$ \\
\hline 8 & Peshawar & 982,816 & 566,248 & 3.29 & $1,386,529$ \\
\hline 9 & Quetta & 565,137 & 285,719 & 4.09 & 871,643 \\
\hline 10 & Islamabad & 529,180 & 204,364 & 5.7 & 972,669 \\
\hline
\end{tabular}

\section{Table $1.3^{7}$}

Karachi is known as "mini Pakistan" for many obvious reasons. Since the establishment of Pakistan no other city attracted more internal migrants than Karachi. The reasons for the in-country migration are varied from government to government. The major premise of this study is based upon the preposition that population increase is the central cause of mismanagement. The decade wise study of demographic change in Karachi reveals divers patterns since the creation of Pakistan. Table 4 helps in understanding the pattern of causes under successive governments.

\footnotetext{
Ibid. 1095

Economic Survey of Pakistan, 2010-2011, 243
} 
The increase in Karachi's population since independence, reasons and type of population.

\begin{tabular}{|c|c|c|c|c|}
\hline Years & $\begin{array}{l}\text { Nature of } \\
\text { government }\end{array}$ & $\begin{array}{l}\text { Population } \\
\text { increase in } \\
\text { \%age }\end{array}$ & $\begin{array}{l}\text { Major causes of } \\
\text { migration }\end{array}$ & $\begin{array}{l}\text { Types of } \\
\text { immigrants }\end{array}$ \\
\hline 1947-1951 & $\begin{array}{l}\text { Formative } \\
\text { phase, } \\
\text { governments } \\
\text { worked } \\
\text { under } \\
\text { interim } \\
\text { constitution }\end{array}$ & $\begin{array}{l}43,5887 \text { to } \\
1,064,557 \\
\mathbf{5 9 . 0 5 \%}\end{array}$ & Partition & Refugees \\
\hline 1951-1961 & $\begin{array}{l}\text { Government } \\
\text { under } \\
\text { political } \\
\text { instability }\end{array}$ & $\begin{array}{l}1,064,557 \\
\text { to } \\
1,912,598 \\
\mathbf{4 4 . 3 3 \%}\end{array}$ & $\begin{array}{l}\text { Partition, status } \\
\text { of capital and } \\
\text { industrialization. }\end{array}$ & $\begin{array}{l}\text { Migrants } \\
\text { from India } \\
\text { Govt. } \\
\text { servants } \\
\text { Job seekers }\end{array}$ \\
\hline 1961-1972 & $\begin{array}{l}\text { Martial Law } \\
\text { under Ayub } \\
\text { Khan and } \\
\text { Yahya Khan }\end{array}$ & $\begin{array}{l}1,912,598 \\
\text { to } \\
3,515,400 \\
\mathbf{4 5 . 5 9 \%}\end{array}$ & $\begin{array}{l}\text { Industrialization, } \\
\text { political and } \\
\text { creation of } \\
\text { Bangladesh }\end{array}$ & $\begin{array}{l}\text { Job seekers } \\
\text { Political } \\
\text { voters } \\
\text { Refugees } \\
\text { from East } \\
\text { Pakistan }\end{array}$ \\
\hline 1972-81 & $\begin{array}{l}\text { Democratic } \\
\text { govt. under } \\
\text { Bhutto and } \\
\text { Martial Law } \\
\text { under Zia }\end{array}$ & $\begin{array}{l}3,515,400 \\
\text { to } \\
5,208,000 \\
\mathbf{3 2 . 5} \%\end{array}$ & $\begin{array}{l}\text { Govt. policies of } \\
\text { quota system. }\end{array}$ & $\begin{array}{l}\text { Job seekers } \\
\text { Politically } \\
\text { employed }\end{array}$ \\
\hline 1981-1998 & $\begin{array}{l}\text { Zia till } 1988 \\
\text { then four } \\
\text { democratic } \\
\text { govt. by } \\
\text { Benzair and } \\
\text { Nawaz }\end{array}$ & $\begin{array}{l}5,208,000 \\
\text { to } \\
9,856,000 \\
\mathbf{4 7 . 1 5 \%}\end{array}$ & $\begin{array}{l}\text { Carry-over of } \\
\text { previous policies }\end{array}$ & $\begin{array}{l}\text { Carry-over } \\
\text { of previous } \\
\text { policies. }\end{array}$ \\
\hline $\begin{array}{l}\text { 1998- } 2015 \\
\text { (estimated) }\end{array}$ & $\begin{array}{l}\text { Military } \\
\text { regime under } \\
\text { Musharaf }\end{array}$ & $\begin{array}{l}9,856,000 \\
\text { to } \\
20,000,000\end{array}$ & $\begin{array}{l}\text { Development, } \\
\text { military } \\
\text { operations in }\end{array}$ & $\begin{array}{l}\text { Job seekers } \\
\text { and } \\
\text { Internally }\end{array}$ \\
\hline
\end{tabular}




\begin{tabular}{|l|l|l|l|l|}
\hline & $\begin{array}{l}\text { then } \\
\text { democratic } \\
\text { governments. }\end{array}$ & $\mathbf{5 0 . 7 2 \%}$ & $\begin{array}{l}\text { North and } \\
\text { natural disasters } \\
\text { in rest of } \\
\text { Pakistan. }\end{array}$ & $\begin{array}{l}\text { Displaced } \\
\text { People. }\end{array}$ \\
\hline
\end{tabular}

\section{Table $1.4^{8}$}

The consistent in-country migration turned Karachi into a multi ethnic city where all ethnic identities of Pakistan are resided in clusters. However, Urduspeaking (including Bengalis, Memon, Kachis) formed a big majority in the city.

For some ethnic groups Karachi holds the largest population of them across the world. For example the largest chunk of Urdu speaking lives in Karachi. Likewise the largest number of Pukhtoons is also residing in Karachi. It is estimated that the number of Pukhtoons in Karachi exceeds the number of Pukhtoons living in Peshawar and Kabul combined together.

Similarly, Karachi also hosts the largest population of Baluchi's in any one city. The capital of Baluchistan Quetta has fewer Baluch's than Karachi. In addition to these communities illegal immigrants from neighboring countries found a safe haven in Karachi ${ }^{9}$.

\section{Karachi: Economic epicenter of Pakistan:}

Pakistan is a developing country. Its economy largely rests upon primary sector and some manufactured products. Karachi is the major center of economy of Pakistan. Karachi is the single largest contributor in terms of tax collection, total revenue, exports and manufacturing. Karachi Stock Exchange (KSE) is the largest stock exchange in Pakistan. Currently there are 560 companies listed with it and the Market Capitalization in April 2015 is $7,305.81$ billion rupees ${ }^{10}$. The mega city provides largest employment pool and best business in Pakistan. One-day strike in the city inflicts huge damage to national exchequer. Denial of the right to govern the city through local government is the bone of contention between local leadership and other power stakeholders both at federal and provincial levels. Karachi is kept in

8 Table generated by author with the help of various census reports.

9 Feroz Ahmed, “Pakistan: Ethnic Fragmentation or National Integration?," The Pakistan Development Review, 35:4 Part II, (Winter 1996): 635, Accessed June 9, 2012. http://www.pide.org.pk/pdf/PDR/1996/Volume4/631-645.pdf. 
unrest for last twenty five year except six years (2002-2008) of President Musharraf regime.

In twentieth century and onwards, cities have assumed the role of economic engines of states. Pakistan's economy is also largely dependent upon its cities. Karachi determines the fate of Pakistan's economy. It accounts for half of government revenues in Pakistan and 20 percent of GDP. It is the country's financial center and only port and has the highest concentration of literate people ${ }^{11}$.

\section{Inaccurate population estimates}

Developing countries like Pakistan have always struggled against skilled management and administrators to run the affairs of the state. Population census is probably one of the most laborious and technical task to handle. However developing countries across the world have always shown weaknesses in this particular aspect of census and Pakistan is no exception. These inaccurate estimates are responsible for faulty planning and development. "Determining what steps governments might take to lessen the shocks of this coming era of giant cities calls for information not available today. It is difficult, for example, to get a fix on something as elementary as the size of the larger cities. In 1992 some estimates put the population of Mexico City at 20 million. Now the United Nations sets the number at 15.6 million--a difference bigger than Baghdad. Karachi may have 9.5 million residents, or it may have 12million; Sao Paulo, at 16 million, has several million fewer than in earlier estimates. Part of the problem is the uncertainty of census data--where there has been a census at all--in nations that do not have the resources to conduct an efficient count and where squatters and legal residents may have sound reasons for evading the tally"12.

Recently the government of Pakistan announced conduction of census in 2011. A mammoth exercise was undertaken the related department. The whole effort was futile because of corruption, political intervention, ethnic representation etc. In Karachi several workers collecting the data for census were murdered in an ethnic squatter settlement. "Three activists of the

11 Eugene Linden, "The Exploding Cities of the Developing World". Foreign Affairs 75.1 (1996): 53

12 Eugene Linden, "The Exploding Cities of the Developing World", Foreign Affairs, (Jan/Feb 1996), Accessed June, 2013. https://www.foreignaffairs.com/articles/1996-0101/exploding-cities-developing-world. 
Muttahida Qaumi Movement (MQM) were gunned down in Mehmoodabad on Tuesday while they were taking a rest during their 'assistance' to government staff engaged in a house count under the recently launched census, officials and party sources said. The second incident of political activists having been killed for a second day running prompted fresh fears among Karachiites, but the killing scourge remained beyond the control of political and security administrations of the province"13. The main driving force behind the census effort of 2011 was the setting of boundaries for constituencies full of voters of different political parties and cut the voter of opponent political parties in such constituencies that they fail to make a successful impact.

Since independence of Pakistan only one census was decennial i.e. 1961. The censuses which were held are, 1951, 1961, 1972, 1981 and 1998. Temporal inconsistencies created serious problems in population enumeration and thus affected resource allocation.

\section{Direct impacts on Karachi:}

\section{Impact of internal migration:}

Among five major cities of Pakistan, Karachi's crime rate is relatively higher than others. The number of criminals in Karachi is at an alarming level. The foremost impact on Karachi of internal migration is crime. The number of police personnel compare to the population they cater to is very low. Over the top of it a large number of them are constantly posted on security and protocol duty of government officials, high ranking officers, politicians and other notables of the city.

The number and condition of police in Karachi is best described by the assessment made by US officials. "The police are only one of several armed groups and probably not the most numerous or best equipped," according to a secret assessment of the 'The Gangs of Karachi' by then US consul general Stephen Fakan in April 2009.14" The working of police in Karachi is handicapped by the training and equipment they receive and have. There is no proper system to check that police is working according to the need and well equipped. Corruption and nepotism further deteriorate the organization and working of police.

13 Dawn, April 12, 2011, http://www.dawn.com/news/620259/three-mqm-workerskilled-in-karachi Accessed June 15, 2014

14 Armed gangs outnumber police in Karachi', Dawn, May 22, 2014, Accessed December 2, 2015. http://www.dawn.com/news/630876/armed-gangs-outnumber-police-in-karachi 
An assessment of the Problems faced by Karachi and Pakistan due to the rapid population growth of the city

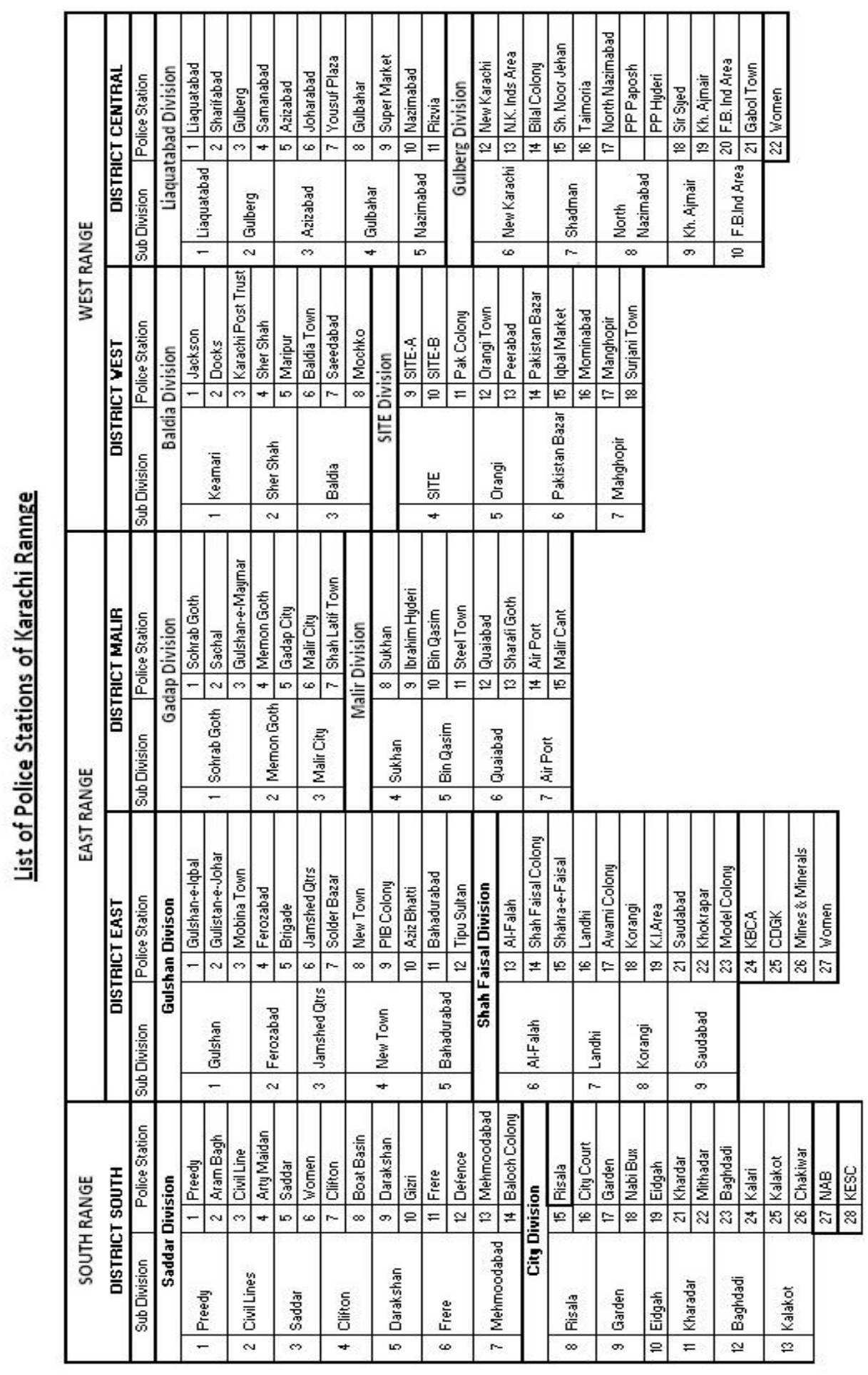

Table 


\section{$\mathbf{1 . 5} \mathbf{5}^{15}$}

\section{Lack of planning}

Pakistan has gone through many difficult times which have taken toll on many aspects of governance planning is the most important among these. Political instability is one of the reasons of the poor planning in Pakistan and has become the worst victim of this. Pakistan Planning Commission, a federal institution responsible for macro level development planning, has hardly given importance to Karachi despite its needs, is a major factor behind lack of planning.

The span of different political regimes has been very short due to which the government prioritize such measure that bring swift and easy popularity for them rather than long term scheme which result into long term and permanent solutions. There are planning commissions formulated by government however their efficiency is nowhere to be seen. The most important element regarding planning impediment is that whenever a government makes plans for next some years it is pulled down from power and new setup starts, which take a new root towards solving the problems faced by the country. The planning in Pakistan is one of the most neglected aspects related to governance and it leads to financial losses in every aspect.

Karachi is also a great example of unplanned and unaccounted growing city. No one knows for sure that how many people come and go out of city and how many will be coming to the city for permanent stay in it. There are estimates related to this issue, however no planning takes place to cater to the problems that might result due to the growth. Today Karachi is facing every possible problem a city can face and on a large scale.

\section{Friction between host population and visitors}

Usually across the world there is a limit to internal migration to any one destination then people start to move towards different directions or destinations. However in the case of Pakistan and Karachi there are not alternates available with such potentials like Karachi despite of its entire law and order situation. Such continuous migration into one destination creates socio, economic and political problems. Heterogynous population in terms of ethnic and sectarianism like Pakistan is already divided into many faults line.

15 http://www.karachipolice.gov.pk/2012/06/11/police-stations/ Accessed May 10, 2014 
In normal circumstances these fault lines lie geographically far from each other. However in Karachi due to the over and ever increasing internal migration these fault line divide the city into many sub cultures in a small geographic space which its participants are not willing to share.

"July may have been the deadliest month of violence of the year so far, but August has certainly been the scariest with the city descending into a freefor-all ethnic warfare. With more than 1,400 killings mostly on ethnic and political grounds this year, the parties having political stakes in Karachi agree that the city is fast dividing along ethnic lines but do not believe that it will adversely affect their stakes or political future" 16 .

\section{Karachi killings Jan 1 to Aug 27, 2011}

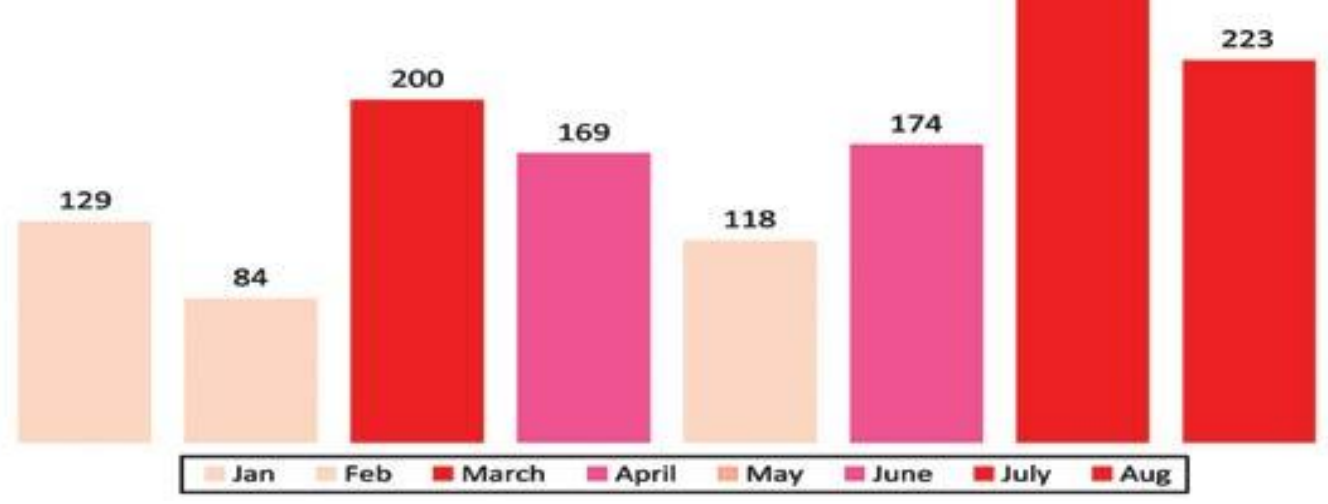

Data of eight months of 2011 of killings in Karachi

\section{Figure $1.1^{17}$}

Due to continuous migration in Karachi, the city develops number of ethnic enclaves. These enclaves are inhibited mostly by labor class but their impact started to feel when they are used in the political gains in the city. It happens

16 Dawn, 27th August, 2011, Accessed June 14, 2014.

http://www.dawn.com/news/655056/ethnic-fault-lines-of-karachi

17 Dawn 27 August, 2011, Accessed June 14, 2014.

http://www.dawn.com/news/655056/ethnic-fault-lines-of-karachi 
in other parts of the world. For instance, in United States number of cities could not afford the tide of immigrants ${ }^{18}$.

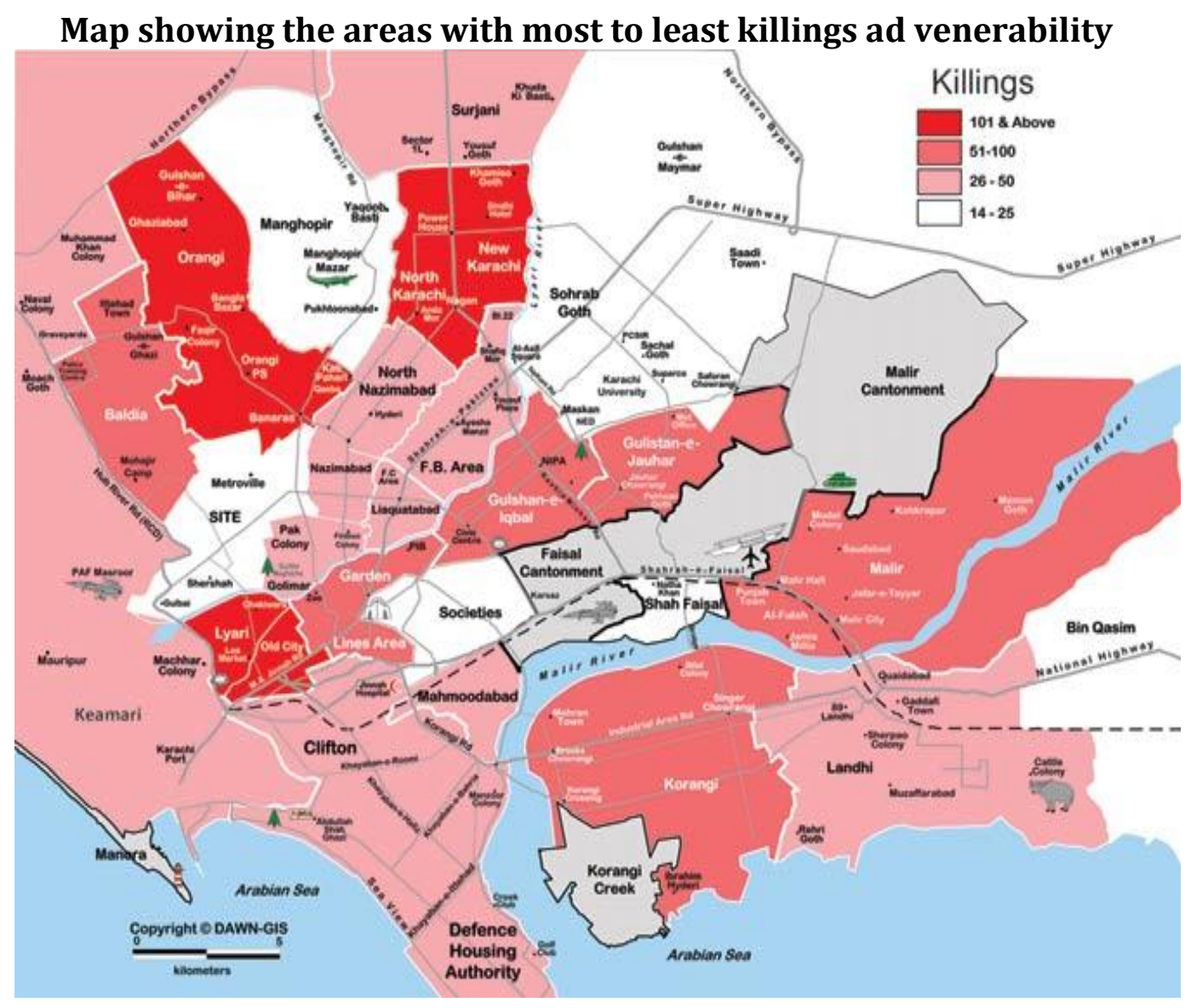

Figure 1.219

\section{More migrants than the available employment opportunities:}

Another issue attached to internal migration is the number of migrants from rural to urban areas and scale of reasons (employment) for which they migrated. It is an established fact that the growth of rural population is always faster than that of urban. "Herrick (1965) reflected the prevailing

18 Poston and Bouvier, Population and Society: An Introduction to Demography, (New York: CUP, 2010), 185.

19 Dawn 27 August, 2011, Accessed June 14, 2014 http://www.dawn.com/news/655056/ ethnic-fault-lines-of-karachi 
view about the desirability of internal migration when he asserted that "in the absence of any movement, when rural fertility exceeds urban fertility, the agricultural labor force will grow faster than industrial employment. Movement from the country to the towns, which is necessary if strictly balanced growth of the two parts of the labor force is to occur, becomes even more important if an increase in the industrial sector is among the goals of the developing economy."'20 In Pakistan the same trend is evident due to the dearth of urban areas. "Numerous studies have now documented the fact that throughout the developing world rates of rural-urban migration continue to exceed rates of urban job creation and to greatly surpass the capacity of both industry and urban social services to absorb this labor effectively"21.

This difference of intake of migrants and lack job availability produces repugnant results. "Migration substantially in excess of new job opportunities is both a symptom of and a factor contributing to Third World underdevelopment"22.

Karachi reached its breaking point decades ago and even today all the people who come to Karachi in search of employment are not satisfied. This is bound to increase because attention towards policy related to internal migration is nonexistent.

\section{Clustering of labor force, resulting in lowering of wages:}

It has been observed that in developing countries and even in some developed countries the job seekers move towards a labor market, which results into clustering of labor force in a particular area. Clustering of labor force into a limited geographical location results into cheap wages, affecting the living standards of laborers. "Economic theory suggests that immigration into a closed labor market affects the wage structure in that market by lowering the wage of competing workers and raising the wage of complements. Most of the empirical studies in the literature exploit the geographic clustering of immigrants to measure the labor market impact of

20 Michael P. Todaro, "Internal Migration in Developing Countries: A Survey," in, Population and Economic Change in Developing Countries ed Richard A. Easterlin (Chicago: University of Chicago Press, 1980): 361, Accessed May, 15, 2012. http://www.nber.org/chapters/c9668.pdf.

$21 \quad$ Ibid 361

22 Ibid 363 
immigration by defining the labor market along a geographic dimensionsuch as a state or a metropolitan area"23.

There is a variation in wages of different labors. Mega cities like Karachi may offer multiple jobs in a particular field for some time depending upon the need and policy of government. However these employment opportunities get exhausted with in short time, creating clustering, low wages, and unemployment. At some point it might seem that wages of a labor or field is high but it can easily be changed according to the demand and supply of labor. Statistics show that the actual wages of particular labors may seem higher than rural areas; however it may be noted that the cost of living in Karachi is also much higher than all cities and rural areas. There is a marked difference of $10 \%$ to $20 \%$ in prices of everyday items in Karachi, like vegetables, milk, yogurt, eggs, meat etc.

\section{Issue of assimilation in Karachi:}

Assimilation is a concept strongly associated with migration. The scholars researching on any aspect of migration and immigrants take assimilation into consideration; perhaps without understanding assimilation of the destination of migration is the most important element. Karachi is no exception. The federation of Pakistan is home to dozens of different cultures and languages, which separate her population. The heterogeneity of the people of Pakistan has been played upon by some political parties to forward their political agendas.

Karachi is the only city where all shades of Pakistani population can be seen. People from farthest North, East, West and South of Pakistan are habitants of Karachi. Usually the numbers of ethnic communities are ignorable in large cities, however in the case of Karachi all communities exists in considerable numbers which cannot be ignored.

Milton Gordon was one of the earlier scholars who initiated to understand the migration and issues attached to it as early as 1960s. "For Gordon, primary structural assimilation represents the most crucial assimilation subprocess. Once this stage takes place, subsequent assimilation sub-processes are expected to ensue automatically. These sub-processes include marital-

23 George J. Borjas, "Native Internal Migration and the Labor Market Impact of Migration", The Journal of Human Resources, XLI (2005): 221-222, Accessed May, 15, 2012. http://www.hks.harvard.edu/inequality/Seminar/Papers/Borjas.pdf 
assimilation (amalgamation), identificational assimilation (ethnic identification), attitudinal receptional assimilation (absence of prejudice), behavioral receptional assimilation (absence of discrimination), and civic assimilation (absence of value or power conflicts). Gordon's assimilationist perspective suggests that once minority group members achieve primary structural assimilation, they are likely to intermarry with members of the majority group, to shed their ethnic identities in favor of an American identity, to be less likely to experience prejudice and discrimination, and to hold universal—as opposed to particularistic — values and interests" 24 .

Assimilation is closely related to acculturation. At this stage it becomes imperative to embark upon the concept of acculturation. There are many definition of it however the most authoritative was given by, Subcommittee on Acculturation, 1930. "Acculturation comprehends those phenomena which result when groups of individuals having different cultures come into first-hand contact, with subsequent changes in the original cultural patters of either or both groups"25.

As a result of ever increasing demographic transformation of Karachi the issue of Assimilation remains unsolved. It further branch out into problems of class, race, ethnicity, socio economic conflict etc. Thus Karachi as a city is still in search of an identity, usually all cities and towns across the world have a character, culture unfortunately Karachi cannot be defined by any such indicators.

\section{Ethnic conflicts:}

Cities like Karachi have a common tendency of ethnic violence, depending upon the social, political, economic and law and order conditions. Even little negligence in terms of law and order can accumulate to violence. When all the national ethnic entities melt down into a limited geographic area, friction between them is bound to occur. One of the earliest ethnic violence on a large scale was reported on $5^{\text {th }}$ Jan. 1965 when Gohar Ayub, son of the then President General Ayub Khan lead a victory procession through the heart of population of political opposition. Since then the frequency of ethnic based

24 Rogelio Saenz and M. Cristina Morales, "Demography of Race and Ethnicity," Handbook of Population ed Dudley L. Poston \& Michael Micklin (New York: Kluwer Academic/Plenum Publishers, 2005), 182

25 Milton Gordon, The nature of Assimilation (New York: Oxford University Press, 1964), 61 
violence is increasing and in recent days it is the leading source of stories for daily news. "More specific social and economic factors identified in the literature as contributing to violence include oppression of minorities, economic grievances, historical precedents, competition for resources, favoritism, availability of resources for violence, security fears, mobilization by elites, weak social ties, national ethnic diversity, territorial claims, religious or political polarization, incendiary media, and international influences"26.

Along with the mentioned reasons for ethnic confrontation the population of Karachi has another unique reason, sub-ethnicities. "In highly mixed regions, groups of the same type are not large enough to develop strong collective identities, or to identify public spaces as associated with one or another cultural group. They are neither imposed upon nor impose upon other groups, and are not perceived as a threat to the cultural values or social/political self-determination of other groups. Partial separation with poorly defined boundaries fosters conflict. Violence arises when groups are of a size that they are able to impose cultural norms on public spaces, but where there are still intermittent violations of these rules due to the overlap of cultural domains" 27.

The friction and violence increases when an ethnic group reaches a particular size and is at a comfortable position compared to other groups, who resort to agitation and violence for their voice to be heard. "When groups are larger than the critical size, they typically form self-sufficient entities that enjoy local sovereignty. Hence, we expect violence to arise when groups of a certain characteristic size are formed, and not when groups are much smaller or larger than this size"28.

Due to the unique socio, ethnic, economic and political conditions of Pakistan and especially Karachi then chances of incidents of ethnic violence increases. The history and records of violent incidents in Karachi reveals the staggering numbers and steep increase with the increase in population. The comparison of these numbers show a huge difference of such events in Karachi compared to other parts of Pakistan.

26 May Lim, "Global Pattern Formation and Ethnic/Cultural Violence", Sciencemag, VOL 317, (September 2007): 1540, Accessed May 18, 2012 www.sciencemag.org

27 Ibid 1541

28 Ibid 1541 


\section{Health and epidemics}

One of the most important effects of high rate of population increase in any area is threats to health of citizens of that area. Since man has started to establish and live near animal farms, new diseases have attacked him. With the increase of population, specifically in close proximity the hygienic conditions decrease, increasing the chances of risks to health.

Most of the diseases are due to unhygienic and synthetic conditions of urban dwellers, which do not occur in rural areas. Many epidemics hit Karachi regularly. One of the most recent and feared is the Dengue Fever which visits Karachi almost every year. Due to the ever increasing population of Karachi it is almost impossible for local authorities to eradicate Dengue Fever from the city. There are thousands of suitable places where Dengue mosquito thrives and nothing could be done to control it.

The failure in eradication of polio virus is also has links with the demographic transformation of Karachi. Every day thousands of people come to Karachi and they are unaccounted for. They bring all the diseases and ailments along with them. Pakistan is the only country in the world which has been trying to eradicate polio and still not been able to achieve a polio clean flag from WHO. One main reason for the existence of polio virus in Karachi is its squatter settlements and Jhuggi Abadis. "Cities have historically been associated with the evolution of ideas of public health and practice. The modern public health revolution began in European cities in the 19th century where, under the pressures of industrialization, poverty, crowding and the breakdown of traditional ways of living, the conditions of daily life had deteriorated for most people"29.

Poor health conditions leads towards increase in death ratio. Malaria is the worst enemy of mankind. It has been estimated that Malaria is the single largest cause of human death since the beginning of life. Even today across the world where ever Malaria producing mosquitos are allowed to flourish they tend to affect the human population around them. Karachi due to its demographic patterns is a safe haven for it. Every year Malaria is responsible

29 Anthony J. McMichael, "The Urban Environment and Health in a World of Increasing Globalization: Issues for Developing Countries", Bulletin of World Health Organization, 78 (9), (2000): 1117, Accessed May 30, 2012. http://www.scielosp.org/pdf/bwho/ v78n9/v78n9a07.pdf. 
for hundreds of deaths in the city. There is even a squatter settlement by the name of "Machar Colony", means "Mosquito Colony". This town got its name because of obvious reasons of high number of mosquitos and malaria cases.

\section{Satellite image showing a slum area (Katchi Abadi)}

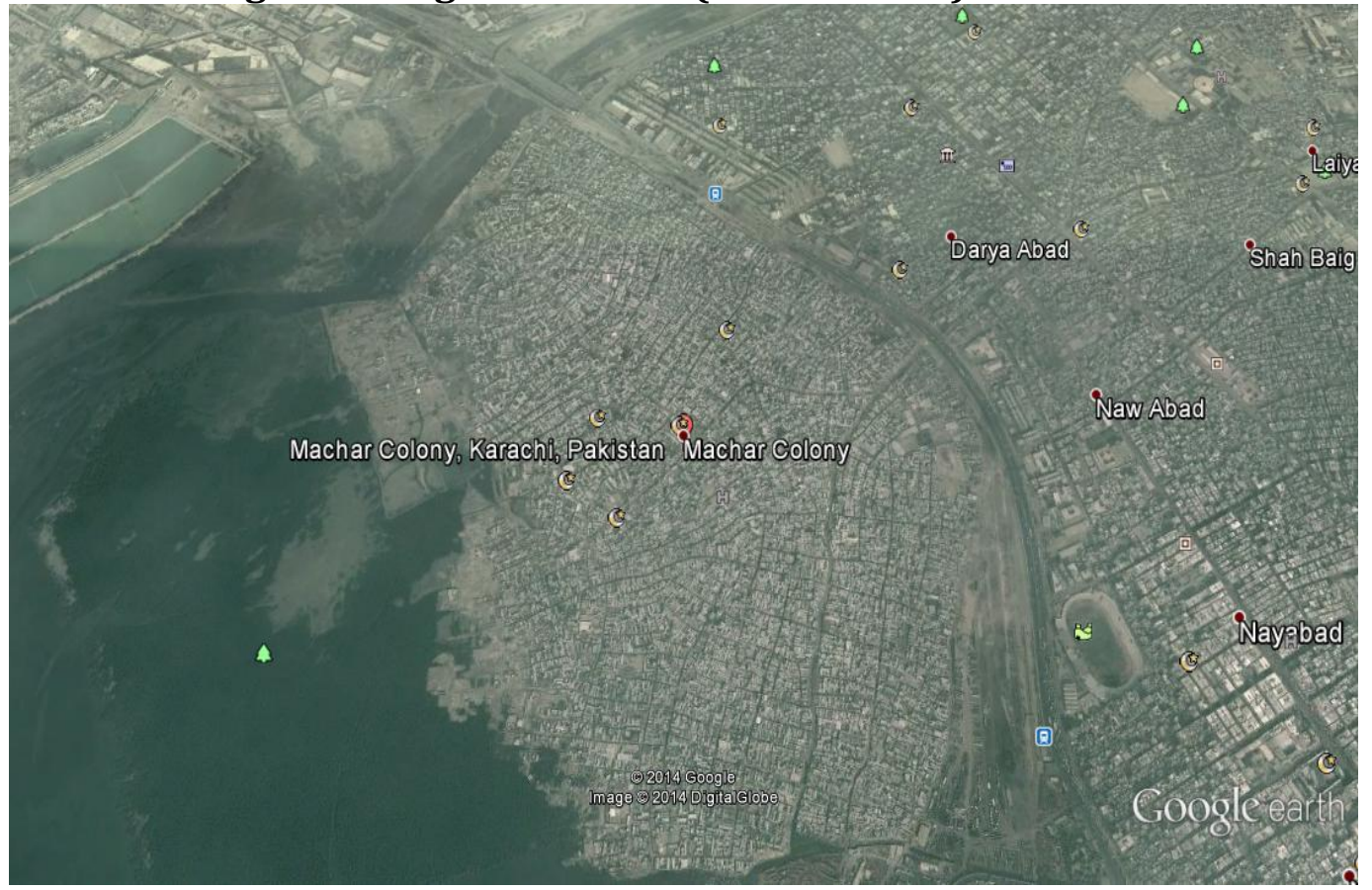

\section{Figure 1.3 $3^{30}$}

"We sought to describe the circulation and emergence of cholera strains in Karachi, a rapidly developing megacity of South Asia with a population estimated at about 11 million. Despite a robust economy, a rapidly expanding population combined with civil unrest and a crumbling infrastructure deny basic sanitation and clean water to many of its inhabitants. We accessed computerized laboratory reports from June 1990 to August 1996, and extracted data on isolates of $V$. cholera over that period in a busy hospital microbiology laboratory serving both inpatients in a tertiary care facility and outpatients from all over the city ${ }^{31 "}$

$30 \quad 24^{\circ} 51^{\prime} 44.98^{\prime \prime}$ N 66²5'45.99" E, South of Karachi (Google Earth)

31 S. P. Fisher-Hoch et al "Cholera in a developing megacity; Karachi, Pakistan"” Epidemiol Infect 119 (1997): 287-288, Accessed June 20, 2014. http://www.ncbi.nlm.nih.gov/ pmc/articles/PMC2808999/pdf/9440430.pdf. 


\section{Squatter settlements:}

Squatter settlements are a matter of grave concern for any urban center. Across the world in mega cities a mushroom growth of squatter settlements is a common phenomenon. However the size, number and rate of growth vary from city to city. In developed countries usually the urban destinations of rural population are numerous and their governments are capable of supporting such population. Even in some developing countries like India and Indonesia the number of urban centers is considerable due to which the size, number and growth rate are comparatively under control.

On the contrary there are few parallels of Karachi in the world. Due to lack of urban centers with all the facilities like education, medical, employment etc. in Pakistan, Karachi bears all the burden of rural urban migration of most of Pakistan.

Karachi is host to numerous squatter settlements. The number squatter settlements in Karachi are subsequent to only Calcutta and Mumbai. The emergence of these settlements is a postcolonial phenomenon. Since the independence people from all across Pakistan have seen Karachi as solution to all the economic glitches of their lives.

Along with the number of these settlements the size of them is also considerable. According to Arif Hassan Korangi is one of the largest squatter settlements in $\mathrm{Asia}^{32}$. It hosts a population which is larger than many cities of the world. The population living in squatter settlements in Karachi constitutes a considerable proportion of total population of Karachi. It is estimated that around 15 to 25 percent of total population of Karachi lives in squatter settlements.

Squatter settlements are always a nemesis of policy maker and local administration. The rate at which the population and size of squatter settlements increase is consummate. The capacity of these settlements to absorb people is farfetched. In the recent past since 2005 a sequence of natural disasters struck Pakistan. "On October 8, 2005, an earthquake measuring 7.6 on the Richter scale struck Kashmir and Northern areas. The

32 Arif Hasan is an architect and urban planner, who has been working in and on Karachi since 1970's. His work on the development and physical expansion of Karachi has highest value amongst scholars. http://arifhasan.org 
earthquake resulted in more than 80,000 fatalities, 200,000 people injured and more than four million people left homeless. The main quake was followed by more than 978 aftershocks until October $27^{\prime \prime 33}$. As a result a large number of people moved to Karachi's squatter settlements, because almost every alternate family in earthquake affected area had someone amongst them working in Karachi.

The floods of 2010 and 2011 were the worst floods Pakistan had ever faced. They affected all of Upper and Lower Indus plain and the lives of more than 25 million people were changed permanently. Again Karachi received the largest number of flood affected population. Other than increasing the already existing squatter settlements new settlement also emerged. "About 10,000 more flood survivors arrived at various relief camps established by the City District Government Karachi (CDGK) during the last 24 hours raising the total number of internally displaced persons (IDPs) at the 41 camps to over 56,000, a statement issued on Tuesday evening said"34. These flood victims and IDPs were reluctant to go back to their home town because of two major reasons. Firstly they have lost everything in the floods and the government efforts to resettle them in their original areas are non-existent and secondly they are now exposed to a comparatively better life style in Karachi. Today IDP camps on super highway in Gadap Town have turned into Katchi Abadi and there are here since 2010.

Another factor since 2005 resulted into mass migration towards Karachi, war on terror. In 2008-9 when Pakistan army finally decided to action against the lawlessness in Swat they asked the population to vacate the area to avoid destruction. Again most of the people who vacated the target areas headed towards Karachi because of their relatives were working here and they saw their chances to get settled in Karachi as well.

All these are some recent examples which increased the size and number of squatter settlements in Karachi. Learning from past the Sindh government is going to take notice and control the influx of IDPs due to "Operation Zarb-e$A z b^{\prime \prime 35}$. "'The meeting mulled over the situation threadbare and took some

Timeline of major earthquakes in Pakistan, Dawn, 25 Sep. 2013, http://www.dawn.com/news/1045343 Accessed June 6, 2014

34 Dawn $1^{\text {st }}$ September 2010, http://www.dawn.com/news/558781/cdkg-facing-noserious-problem-in-handling-flood-of-idps Accessed June 20, 2014

35 A military operation started by Pakistan Army against Taliban strong hold in North Waziristan on $15^{\text {th }}$ June 2014. See Dawn 16 th June 2014 
crucial decisions to make it sure that Sindh - Karachi in particular - should not be used as a rendezvous as it had been following the previous military operation," said a minister in the provincial government" 36 .

\section{Map showing Katchi Abadis in Karachi:}

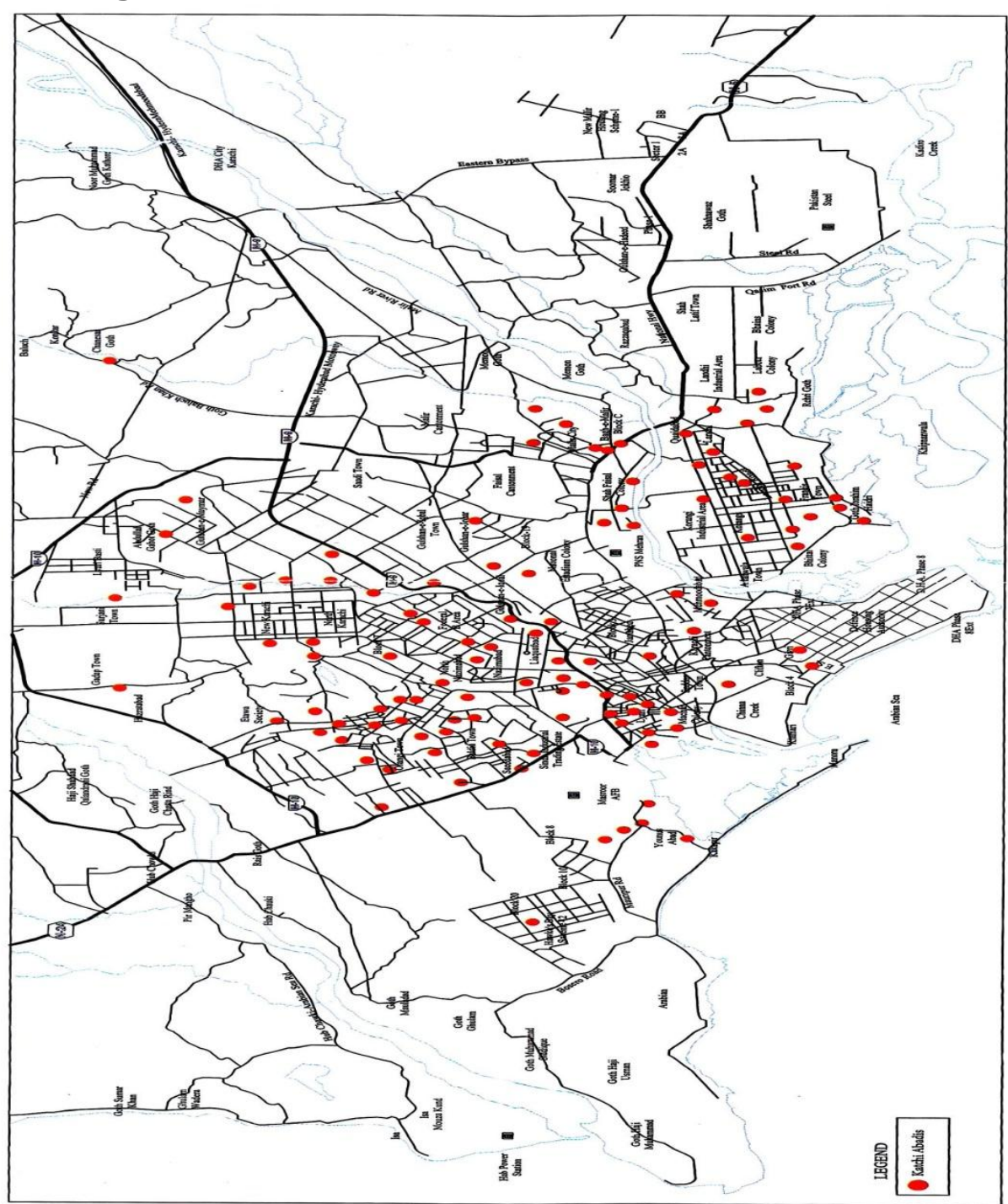

Figure1.437

Dawn, 26 Feb. 2014, http://www.dawn.com/news/1089426 Accessed June 20, 2014

Arif Hasan et al., Karachi: the Land Issue (Karachi: Oxford, 2015), Map VII 


\section{Indirect impacts on Pakistan: Draining workers from all over Pakistan:}

Contrary to the points mentioned above the areas from where the internal migrants pour into Karachi suffer a lot. There are two categories of internal migrants first those who move due to "pull factors" and other move due to "push factors". It has been noted that majority of the "pull factor" migrants who tend to or take initiative to migrate to Karachi are little more educated than the rest of the home or source population. This leads to stagnation of that particular area in the sense that the capable and more skilled people leave towns and villages. The ratio of growth and development of Karachi is far more than any other city, town or village of Pakistan. "Hence, their departure lowers the overall level of educational attainment in the area of origin and often deprives the area of persons with skills that might be very useful. These migrants tend to be more innovative and are often better planners. Indeed, that is one reason why they chose to move in the first place"38.

In long term the source area does not get develop due to lack of human resource and skilled labor. The paradigm of parallel development all across the country gets shattered. The influx of money from urban to rural creates a false impression that the rural buying power of rural population is increasing.

\section{Education:}

Education is another aspect affected by the rapidly transforming demography of Karachi. Although Karachi has the highest literacy rate in Pakistan, it has yet lot to offer to its citizens. For the last two decades the education system in Karachi has taken a vicious turn. Till 1980s the number of students studying in government institutions was significant. Government provided most of the institutions at a low cost.

In recent years the price of education has arisen to unprecedented levels. The population in increasing and government is unable to provide schools, colleges and universities to cater all students. This vacuum is great fully filled by private institutions. As a consequence the cost of education has reaches

38 Dudley L. Poston \& Jr., Leon F. Bouvier, Population and Society: An Introduction to Demography (New York: Cambridge University Press, 2010), 175 
new heights. The number of secondary schools registered with Board of Secondary Education Karachi is $5812^{39}$. Less than $25 \%$ of the schools are government schools.

Education is directly related to the demographic transition. It is an established fact that educated couples tend have small families and their fertility rate is much lesser than those of uneducated couples. In Karachi as well the rate of fertility of squatter settlements is much higher than those of high value residential areas because of the difference of education between the resident populations. Other than the general education the education of women is more important.

"One current hypothesis is that an increase in women's level of education and women's labor participation will decrease fertility. According to Ruth Dixon-Mueller (Dixon-Mueller, 1993), education for women can indirectly decrease fertility in three ways. Increasing the number of years that women are in school delays marriage and reduces the time duration that women are exposed to the possibility of conception. Education creates aspirations for higher standard of living, thereby decreasing the desired number of children in a family. Education exposes women to "knowledge, attitudes, and practices favorable to birth control" that would enable women to have their desired number of children. Dixon-Muetler also suggests that increased labor participation gives women "alternative sources of social identity and economic support [thereby reducing] women's dependence on men and children" (Dixon-Mueller, 1993, pp. 121-123)"40.

A study done on Japan to understand the impact of education in the fertility rate proved that with increase in enrolment of women in educational institutes the rate of fertility declined.

39 See http://bsek.edu.pk/home/images/stories/other-docs/school-list.pdf official website. Accessed June 21, 2014

40 Kristi McClamroch, "Total Fertility Rate, Women's Education, and Women's Work: What Are the Relationships?," Population and Environment: A Journal of Interdisciplinary Studies Volume 18, Number 2, (November 1996): 176, Accessed June 21, 2014. http://deepblue.lib.umich.edu/bitstream/handle/2027.42/43487/111112005 Article BF02208410.pdf?sequence=1. 


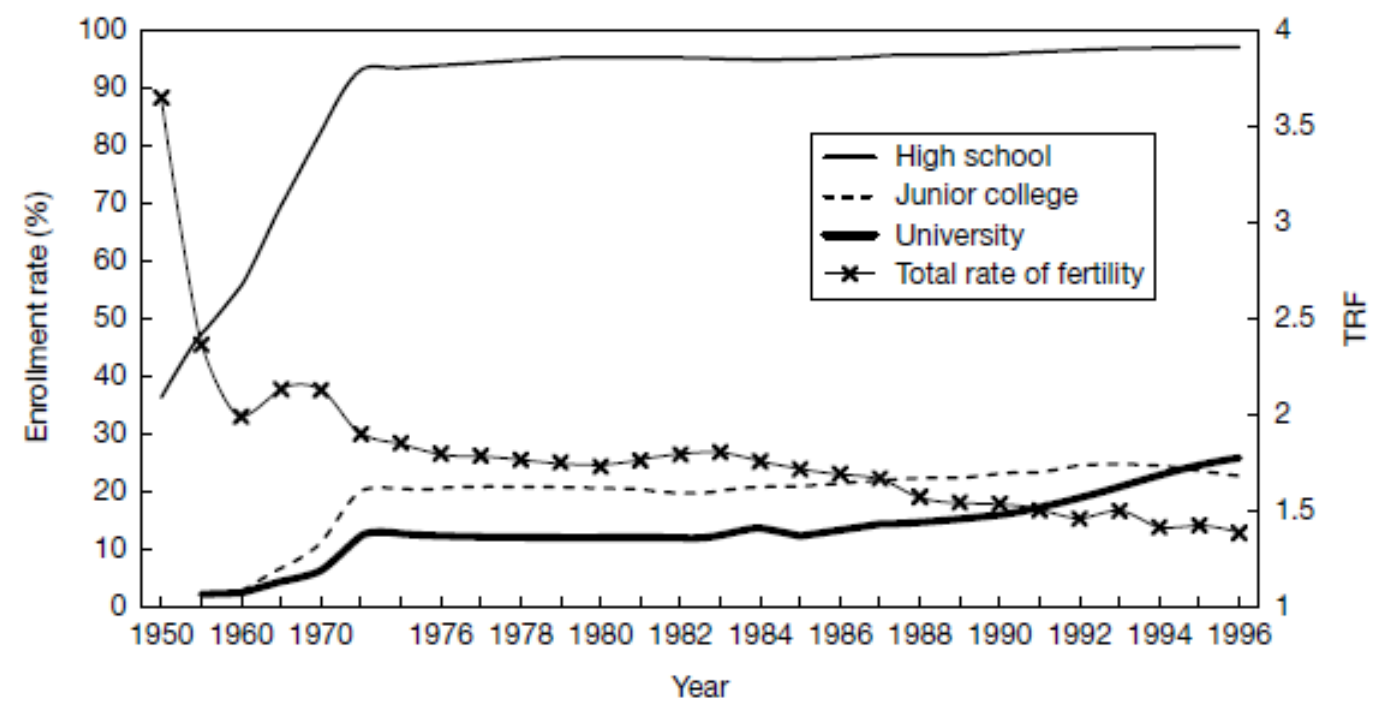

Figure 1 Trends in women's school enrollment and the total rate of fertility, 1950-1996

\section{Figure $1.5^{41}$}

\section{Funding of non-state actors through organized crimes:}

The number of organized crimes is always associated with the size and heterogeneity of a city. Across the world it is a common trend that organized crimes in large cities like Karachi are a big problem for law and enforcement institutions ${ }^{42}$. Then there is a difference between the developed and underdeveloped countries regarding the control over such crimes. Here two such crimes of abduction and armed theft need to be discussed.

According to the reports of Police Department of Karachi organizations banned in Pakistan operate within Karachi for generation of finance ${ }^{43}$. Most of the abductions and armed thefts reported to police are being conducted by highly skilled professionals who only aim to gain money swiftly for their

41 Shirahase Sawako "Women's increased higher education and the declining fertility rate in Japan," Review of Population and Social Policy 9 (2000): 49, Accessed June 21, 2014. http://websv.ipss.go.jp/publication/e/R s p/No.9 P47.pdf.

42 See, Mitchell B. Chamlin and John K. Cochran, "An Excursus on the Population Size-Crime Relationship," Western Criminology Review 5(2), 119-130 (2004), Accessed 27-6-2014. http://wcr.sonoma.edu/v5n2/manuscripts/chamlin.pdf.

43 See Sindh Police, http://www.sindhpolice.gov.pk/annoucements/crime stat ccp karachi. asp Accessed June 27, 2014 
criminal activity or any other such activities. This money is usually spent against Pakistan or some time against neighboring countries of Pakistan.

"With threats ranging from militancy to targeted killings and street crimes to kidnapping for ransom, Karachi is battling organised criminal gangs, armed wings of political parties and members of banned outfits in the 18 million people city with merely 30,000 policemen and still a majority of the force is deployed for security of influential individuals, foreign missions and assigned administrative jobs" 44 .

\section{Alarming increase in population}

It is estimated that the total population of Pakistan will increase by 60 million people with in next 15 years. According to these figures Karachi's population with increase by 6 million. "According to the UN Population Division's latest mid-range demographic projections, released in 2009, the population will rise to 335 million by 2050 . More than 60 million people are expected to be added in just the next 15 years" 45 . This increase is only calculated on the basis of fertility rate, which can be true for Pakistan but for Karachi we will have to consider the rate of migration into the city too. So it would be save to say that Karachi's population will increase by more than $35 \%$. Today Karachi has 20 million people and after 15 years the number would be 26,5 million.

Dawn, $8^{\text {th }}$ July 2013, http://www.dawn.com/news/1023521 Accessed June 27, 2014

Michael Kugelman and Robert M. Hathaway, Reaping the Dividend Overcoming Pakistan's Demographic Challenges (Washington DC: Woodrow Wilson International Center for Scholars, 2011), 6. 


\section{The Growth of Karachi's Urbanized Area over time:}
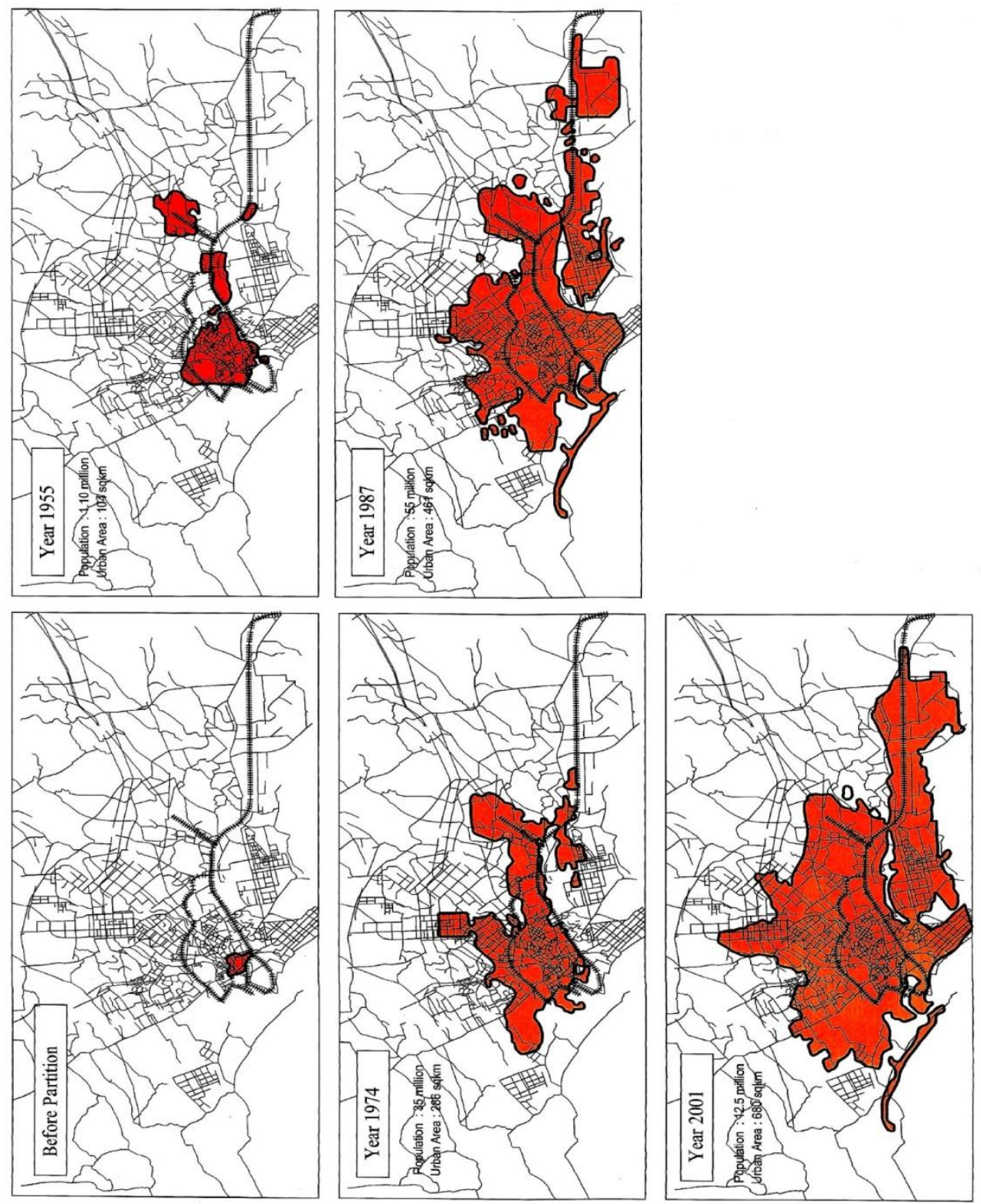

The facts and debate undertaken in this study portrays the dismal state of affairs in terms of dealing with challenges faced and posted by the mega-city, Karachi. The study reveals that since independence the successive administrations have failed to realize the magnitude of issues of the over

46 Arif Hasan, Karachi, Map II, 3 
grown cities and have not given the necessary attention towards the resolution of the problems that arise due to it. The study exposes the fact that time has arrived to take steps should to arrest the situation and work towards providing solutions. It has become imperative, more than ever, to accept the fact that the mega-city has become a den of problems and the efforts taken towards the solutions are not enough to address the situation.

It is recommended to gauge the high rate of population growth of Karachi. It could be addressed through controlling the migration into the city from other parts of Pakistan. Later on Karachi should be on the priority list of both federal and provincial governments, because through Karachi they earn the highest revenue compared to other parts of Pakistan and Sindh respectively. The expansion of the city must be halted for some time to focus upon the given challenges. Lastly the allocation of funds for the Karachi are not enough to manage a city of this magnitude. Resource allocation in any federation is always a challenge, however it must be sorted out before Karachi can achieve its full potential productivity. 
Jhss, Vol. 7, No. 1 , January to June, 2016

\section{References}

Ahmed, Feroz, "Pakistan: Ethnic Fragmentation or National Integration?," The Pakistan Development Review, 35:4 Part II, (Winter 1996)

Borjas, George J., "Native Internal Migration and the Labor Market Impact of Migration", The Journal of Human Resources, XLI (2005)

Burton, Richard F., Scinde or The Unhappy Valley Vol. 1 (London: Richard Bentley, 1851)

Economic Survey of Pakistan 2014-2015, 101

Economic Survey of Pakistan, 2010-2011, 243

Gordon, Milton, The nature of Assimilation (New York: Oxford University Press, 1964)

Hasan, Arif et al., Karachi: the Land Issue (Karachi: Oxford, 2015

Hoch, S. P. Fisher- et al "Cholera in a developing megacity; Karachi, Pakistan”" Epidemiol Infect 119 (1997)

Karim,Mehtab S. “Changing Demographic, Social and Economic Conditions in Karachi City, 1959-94: A Preliminary Analysis," The Pakistan Development Review, 34: 4 Part III (Winter 1995) 
Lim, May, "Global Pattern Formation and Ethnic/Cultural Violence", Sciencemag, VOL 317, (September 2007)

Linden, Eugene, "The Exploding Cities of the Developing World," Foreign Affairs, Vol. 75, No. 1 (Jan. - Feb., 1996)

Linden, Eugene, "The Exploding Cities of the Developing World". Foreign Affairs 75.1 (1996)

McMichael, Anthony J., "The Urban Environment and Health in a World of Increasing Globalization: Issues for Developing Countries", Bulletin of World Health Organization, 78 (9), (2000)

Pakistan Demographic Survey 2000, Federal Bureau of Statistics

Poston and Bouvier, Population and Society: An Introduction to Demography, (New York: CUP, 2010)

Poston, Dudley L. \& Bouvier, Jr., Leon F., Population and Society: An Introduction to Demography (New York: Cambridge University Press, 2010)

Rogelio Saenz and M. Cristina Morales, "Demography of Race and Ethnicity," Handbook of Population ed Dudley L. Poston \& Michael Micklin (New York: Kluwer Academic/Plenum Publishers, 2005) 
Jhss, Vol. 7, No. 1, January to June, 2016

Todaro, Michael P., "Internal Migration in Developing Countries: A Survey," in, Population and Economic Change in Developing Countries ed Richard A. Easterlin (Chicago: University of Chicago Press, 1980) 